\title{
Islam and Muslims in "non-religious" Japan: caught in between prejudice against Islam and performative tolerance
}

\author{
Yoko Yamashita* (ib \\ Graduate School of International Culture and Communication Studies, Waseda University, Shinjuku-ku, Tokyo 169-8050, \\ Japan \\ *Corresponding author. Email: yoko.yamashita11@toki.waseda.jp
}

(Received 30 April 2020; revised 2 January 2021; accepted 10 January 2021)

\begin{abstract}
This paper examines how Islam in Japan tends to be tolerated as (foreign) "culture," especially within the framework of tabunka kyōsei, multicultural coexistence, and cosmetic multiculturalism to circumvent religious apathy, phobia of religion, and prejudice against Islam. In doing so, this paper will: first provide a history of Muslim-Japanese relations and Muslim communities in Japan as well as an overview of the total estimate of the Muslim population in Japan as of 2018; historicize and denaturalize religious apathy, phobia of religion, and prejudice against Islam among the general Japanese public; analyze the rhetoric of tabunka kyōsei and its relation to cosmetic multiculturalism as well as its problematics; investigate the cases of local oppositions to the building projects of mosques and my observations made at events organized by Muslim groups; and conclude with a critical remark on the cosmetic multiculturalist understanding of "Islamic culture" and its approach to tabunka kyōsei.
\end{abstract}

Key words: Cosmetic multiculturalism; Islam; Islamophobia; Japan; multicultural coexistence; Muslims

\section{Introduction}

Islamophobia, defined as "prejudice against, hatred towards, or fear of the religion of Islam or Muslims" and "a multi-faceted problem of arbitrary limitations on religious freedom, unlawful (religious and intersectional) discrimination and social exclusion of Muslim groups and individuals" ${ }^{2}$ has become a global phenomenon and has been on the rise since September 11, 2001. Scholars have pointed out how the reappropriation and recirculation of nineteenth-century colonial discourse on Islam as an inherently backward and violent religion that oppresses women, already evident in the pre-9/11 "representations of a monolithic, enraged, threatening, and conspiratorially spreading Islam," 3 have been proliferated in the aftermath of the $9 / 11$ attacks, especially by the U.S. government in its attempts to morally justify its military actions in Afghanistan and Iraq. ${ }^{4}$ In the European context, it is a well-known fact that restrictions on the wearing of the hijāb, the Islamic headscarf, in both public and private settings, whether by public school teachers and students or private sector employees, have been instituted in many states, increasingly so in the aftermath of $9 / 11$. In addition, a growing number of European states are taking restrictive measures against the wearing of the face-veil in all or some public places despite the fact that it is only worn by a small minority of Muslim women in Europe.

\footnotetext{
${ }^{1}$ The European Commission against Racism and Intolerance 2015, p. 15.

${ }^{2}$ Trispiotis 2017, p. 8.

${ }^{3}$ Said 1997, p. xxviii.

${ }^{4}$ See, e.g., Asad 2003; Haddad, Smith, and Moore 2006.

(C) The Author(s), 2021. Published by Cambridge University Press. This is an Open Access article, distributed under the terms of the Creative Commons Attribution licence (http://creativecommons.org/licenses/by/4.0/), which permits unrestricted re-use, distribution, and reproduction in any medium, provided the original work is properly cited.
} 
Academic research on the Muslim population in Japan is still at a nascent stage. Many previous studies have concentrated on Muslim migrant workers, who came to Japan in the mid-1980s and early 1990s to fill the labor shortage that was caused by Japan's "bubble economy" which lasted from 1986 to 1991, mostly men who were in their twenties and thirties, as well as their Japanese wives and children, from the perspectives of sociology, migration studies, social welfare studies, human rights, cultural anthropology, and religious studies or sociology of religion. ${ }^{5}$ Some recent studies have focused on Japanese Muslims, ${ }^{6}$ including autobiographies written by Japanese converts themselves. ${ }^{7}$ Many previous studies on Muslims in Japan have focused on their ethnic or religious practices and the clashes of values and ethnic customs between Muslims and the general Japanese population as part of the larger immigration or foreign worker issue from the perspective of migration studies. However, little attention has been paid to what dominant discourses of religion and multiculturalism frame and mediate the perceptions of Islam and Muslims in the Japanese national imaginary and how these intersect with the experiences and representations of Muslims in post-9/11 Japan.

I hope to contribute to the existing literature in the following ways: I historicize and denaturalize the notion that Japan is a non-religious and religiously tolerant country; I demonstrate that Islamophobia or prejudice against Islam in Japan, combined with religious apathy and phobia of religion along with ignorance, is manifested in the form of fictitious associations made between Islam and fundamentalism/extremism, and Muslims and terrorists; and I show that Islam in Japan tends to be tolerated as (foreign) “culture," especially within the framework of tabunka kyōsei 多文化共生 (multicultural coexistence) and cosmetic multiculturalism, and that this is a means to circumvent religious apathy, phobia of religion, and prejudice against Islam. In order to do so, this paper will: provide a history of Muslim-Japanese relations and Muslim communities in Japan as well as an overview of the total estimate of the Muslim population in Japan as of 2018; historicize religious apathy, phobia of religion, and prejudice against Islam among the general Japanese public; analyze the rhetoric of tabunka kyōsei and its relation to cosmetic multiculturalism as well as its problematics; examine the cases of local oppositions to the building projects of mosques and my observations made at events organized by Muslim groups; and conclude with a critical remark on the cosmetic multiculturalist understanding of "Islamic culture" and its approach to tabunka kyōsei.

\section{A history of Muslim-Japanese relations and Muslim communities in Japan}

It is believed that the Japan's real encounters with the Muslim world began from the end of the Edo period to the early Meiji period and accelerated after Japan's victory in the Russo-Japanese War in 1905 as Japanese Pan-Asian nationalists befriended Muslim nationalists and Pan-Islamists. ${ }^{8}$ In the late Meiji period, the relations between Muslim intellectuals with nationalist and Pan-Islamic views and Japanese nationalists with Pan-Asian views, who hoped to expand Japanese hegemony into Asia by forming alliances with Muslims, were driven by their mutual opposition to Western hegemony. Since the vast majority of the world's Muslim population were either colonized or partially dominated by the European powers, Muslim-Japanese relations in the pre-war period, according to Esenbel, were marked by informal, personal ties, rather than formal diplomatic relations, between Japanese Pan-Asian nationalists, some of whom converted to Islam to serve the imperialist goal, and Muslim diaspora nationalists and Pan-Islamists who, after seeing Japan's defeat of Russia in the Russo-Japanese War, "sought to emancipate themselves from Western imperialist domination with Japan's help as a world power."

\footnotetext{
${ }^{5}$ See Higuchi et al. 2007; Katakura 2004; Komai 2004; Kudo 2008; Miki and Numajiri 2012; Sakurai 2003; Tanada 2015; Terada 2004; Yamagishi 2008.

${ }^{6}$ See Komura 2015, 2019; Sato 2015.

${ }^{7}$ See Higuchi 2007; Kanayama 2011; Kawada 2004, 2011.

${ }^{8}$ Tanada 2015, p. 8.

${ }^{9}$ Esenbel 2011, p. 2. To learn more about the relationship between Pan-Asianism and Pan-Islamism, see Aydin 2007; Brandenburg 2020.
} 
Pan-Islamic intellectuals were initially impressed by Japan's constitution and liberal reforms that preserved traditions as they isometrically hoped for reforms that were both modern and Islamic and some, including Abdürreşid İbrahim, a Russia-born Tatar activist who became a leading figure of the Muslim-Japanese alliance during the pre-war and war years and the first imam of Tokyo Mosque, even wished to see Japan become a Muslim nation so as to reify their vision of Japan as the "savior of Islam."10 After the 1917 Russian Revolution, Japanese Pan-Asian proponents came to view the Islamic policy, kaikyō-seisaku 回教政策 as an anti-communist device against the Soviet Union and China, which gained importance after the Mukden Incident, the subsequent Japanese invasion of Manchuria in 1931, and the Second Sino-Japanese War that began in 1937, and had been implemented as the Japanese government's colonial policy since 1938, first in North China as they saw Hui Muslims as Japan's anti-communist and anti-Han Chinese allies, and later in Java when they made use of Japanese Muslims and local religious leaders to facilitate occupation. ${ }^{11}$ MuslimJapanese relations began to serve political and militaristic purposes in the aftermath of the Japanese invasion of Manchuria as Japan's relations with the European powers worsened.

The Muslim population in Japan that emerged in the late Meiji period was estimated at around 1,000 in the 1930s and 1940s, mainly consisting of Tatars who emigrated from Russia after the revolution and formed the majority of the Muslim population in Japan of the time; Indian merchants, many of whom first settled in Yokohama in the 1890s and mainly exported Japanese textiles to other Asian countries and beyond and later relocated to Kobe with their families following the Great Kanto Earthquake of $1923^{12}$; and Japanese converts, including those who converted for the sake of kaikyō-seisaku. ${ }^{13}$ In 1935, what is believed to be the first mosque in Japan was built in Kobe, funded primarily by Indian merchants, and another one was built by Tatar Muslims in Nagoya in the following year but was destroyed by fire in 1945. In 1938, Tokyo Mosque, funded by major Japanese conglomerates such as Mitsubishi, Mitsui, and Sumitomo, was built as part of the Japanese government's colonial policy pertaining to Islam and its opening ceremony was attended by Japanese military and navy officers along with officials from other countries. Tokyo Mosque, located in Oyama-cho, Shibuya-ku, had to be demolished in 1986 due to its deterioration and was rebuilt in 2000; this time funded by the Turkish government, and is today known as Tokyo Camii. ${ }^{14}$

Although Muslim-Japanese relations that flourished in the pre-war period largely faded from Japanese collective memory, Muslim communities in Japan continued to exist with Japanese Muslims forming the majority in the years following the war as many Tatar Muslims left Japan upon obtaining Turkish citizenship after World War II. Japanese Muslims organized the Japan Muslim Association in 1952, which was recognized as a registered religious organization, shükȳ hōjin 宗教法人, in 1968. The association sends Japanese Muslim students to al-Azhar University in Egypt and other well-known educational institutions in Muslim-majority countries. The Muslim Student Association in Japan was established in 1961 by international students who were studying in Japan and the Islamic Center Japan was set up in 1974, which became a registered religious organization in $1980 .{ }^{15}$ Both the Japan Muslim Association and the Islamic Center Japan offer Islamic classes, administer their own Islamic burial sites in Japan, and engage in other religious, educational, and communal activities.

The 1973 oil crisis prompted an influx of economic migrants into the oil-producing countries in the Gulf region until the slowdown of the Gulf economies and economic migration due to the "oil glut" that began in the early 1980s, which was followed by a rapid increase in Japan's Muslim

\footnotetext{
${ }^{10}$ Esenbel 2011, p. 7.

${ }^{11}$ Shimada 2015, pp. 68-70. To read more about imperial Japan's Islamic policy, see Ando 2014; Kobayashi 2006; Kurasawa 1981; Matsunaga 2008; Omoso 2005; Sakamoto 2008.

${ }^{12}$ Shimizu 2005, pp. 27-28.

${ }^{13}$ Esenbel 2011, p. 11; Tanada 2015, p. 10. For more information on Japan's early encounters with Muslims, see Green 2013; Misawa and Akçadağ 2007; Sugita 2007; Usmanova 2006.

${ }^{14}$ Komai 2004, pp. 199-200.

${ }^{15}$ Ibid., pp. 200-01.
} 
population from the mid-1980s to early 1990s after a period of steady growth in the post-war era. During this period, "newcomer" migrant workers, mostly unmarried men who were in their twenties and thirties, from Muslim-majority countries such as Pakistan, Bangladesh, and Iran came to Japan in large numbers to fill the labor shortage caused by Japan's "bubble economy," especially in the "3K" occupations in the construction and manufacturing industries ${ }^{16}$ Since the Japanese government did not allow non-Japanese low-skilled laborers to work in Japan, many migrant workers were considered to be unofficial entrants through "back" and "side" doors as they had no valid work visas and were mainly either visa-exempt visitors or student and pre-college visa holders.

The number of non-Japanese Muslim residents, including those overstaying their visas, was estimated to have reached over 100,000 in the early 1990 s. $^{17}$ However, in response to the growing concern about an increase in the number of unauthorized workers and visa overstays, aggravated by the negative media portrayals of Iranians as criminals, the Japanese government suspended the visa-exemption agreements with Pakistan and Bangladesh in 1989 and with Iran in 1992. ${ }^{18}$ Although many Muslim migrant workers who married Japanese women remained in Japan, others, including those who overstayed their visas, returned to their countries of origin and the number of incoming migrants from Pakistan, Bangladesh, and Iran sharply declined for a number of reasons, such as the aforementioned suspension of the visa-exemption agreements, the 1990 revision of the Immigration Control Act that imposed a penalty on companies that employed "illegal" migrant workers, the decline in the demand for labor in the wake of the collapse of Japan's bubble economy in the early 1990s, and the 2000 revision of the Immigration Control Act, which established the criminal offence "unlawful stay" for those who entered Japan illegally. Indonesians, on the other hand, have been coming to Japan in large numbers since the mid-1990s as trainees of the Foreign Trainee System and as interns of the Technical Intern Training Program, and also as nursing and care worker candidates since the JapanIndonesia Economic Partnership Agreement (JIEPA) entered into force in 2008. Presently, Indonesians make up the largest Muslim community in Japan.

Many of the Muslim migrant workers who stayed in Japan started their own used car dealership, halal food and restaurant businesses and also began to look for permanent places of worship in the 1990s since the four mosques that were available at the time, Kobe Mosque, Tokyo Mosque, the Indonesian government-owned Balai Indonesia in Tokyo, and the Saudi government-owned Arab Islamic Institute in Tokyo, built in 1935, 1938, 1962, and 1982, respectively, were inaccessible to many of those who worked and lived outside of Tokyo. With donations they collected from fellow Muslims in Japan and abroad, many mosques have been built since the late 1990s and there are now over a hundred musallas, temporary prayer rooms, and mosques across the country, which function as places of worship that serve religious and ritual purposes, serve other communal purposes that unify multicultural Muslim communities, and help the day-to-day life of Muslims as a minority in Japan.

Although there are no official statistics on the current Muslim population in Japan, the size of the Muslim population at the end of June 2018, according to Tanada's estimate, was approximately 200,000, including about 157,000 non-Japanese Muslims and 43,000 Japanese Muslims, of whom 13,000 were presumed to be those who converted upon marriage, 25,000 were either children born to Japanese Muslim parents or to one ethnic Japanese and one non-Japanese parent, 3,000 were naturalized Japanese citizens and their Japanese spouses, and the other 2,000 were those who converted for reasons other than marriage. ${ }^{19}$ The Muslim population in Japan made up about 0.16 percent of Japan's total 2018 population of approximately 127,202,000. ${ }^{20}$ The somewhat artificial and arbitrary nature of population estimates needs to be pointed out here. Aside from the fact that no distinction

\footnotetext{
${ }^{16} 3 \mathrm{~K}$ is a Japanese neologism that stands for kitanai (dirty), kiken (dangerous), kitsui (demeaning).

${ }^{17}$ Tanada 2015, p. 14.

${ }^{18}$ Yamagishi 2008, pp. 104-05.

${ }^{19}$ Tanada 2019a, pp. 253-62. For more details on Tanada's calculation method regarding the number of Japanese Muslims, see Tanada 2018, pp. 109-28.

${ }^{20}$ The United Nations, Department of Economic and Social Affairs, Population Division 2019.
} 
was made between different sects of Islam in any of the estimates mentioned above, those individuals who were counted and labeled as "Muslim" in the estimates may in fact not identify themselves as Muslims and even if they do, the levels of religious observance inevitably vary from person to person: some regularly participate in congregational prayers, others perform the daily prayers privately, and still others do not partake in any religious practices. Such complexity and multiplicity of practices, experiences, and identities of Muslim individuals is not reflected in population estimates, and so while they can help us get a general picture of Muslims living in Japan, the estimates that are given in this section are not meant to construct the image of a homogenized, undifferentiated, collective Muslim "Other" in Japan.

\section{Religion in Japan: Japan as non-religious and tolerant? \\ Religious apathy and phobia of religion}

The Survey on Japanese National Character conducted by the Institute of Statistical Mathematics in 2013 shows that only 28 percent of the respondents answered that they had personal religious faith and 72 percent said they did not have or were not interested in religious faith. When asked about spirituality, however, 66 percent said that religious attitude or spirituality without reference to any of the established religions was important. ${ }^{21}$ The Japanese General Social Survey conducted by Osaka University of Commerce in 2012 also included several questions about religion. ${ }^{22}$ With respect to a question on religious practice, 65 percent of the respondents answered that they did not follow a religion, whereas 23 percent did not practice a religion but had a family religion, and only 10 percent followed a religion. As for membership of religious groups, 91 percent said they were not members of religious groups whereas 7 percent answered they were. The level of trust in religious organizations was considerably low as 65 percent of the respondents said they did not trust religious organizations very much whereas only 30 percent answered likewise for government ministries and agencies, 25 percent for labor unions, 17 percent for major companies, and 9 percent for schools.

The results of the surveys suggest that the vast majority of Japanese people identify themselves as $m u s h \bar{u} k y \bar{o}$ 無宗教, non-religious, meaning they do not personally follow a particular religion, generally do not trust religious organizations, and are not formally affiliated with a religious group, but this does not necessarily mean that they are atheists as many recognize the importance of spirituality and participate in customary practices and rituals that have religious roots. Ama notes that rituals are separated from religion in the "Japanese religious mind," as he calls it, as evidenced by the fact that the two major annual events, hatsumōde, the first visit to Shinto shrines and Buddhist temples during the Japanese New Year holidays and obon, a Japanese Buddhist event of honoring ancestral spirits in late summer, along with Christmas and other Buddhist and Shinto rituals that many Japanese partake in are considered customary, but not religious. ${ }^{23}$ Inagaki argues that the syncretic traditions centered around polytheistic and animistic Shinto brought about "infinite embracement" that formed the basis of Japanese religious thought, which is characterized by immanence rather than transcendence due to the absence of the Absolute, on the condition that the authority of the state remains unchallenged. ${ }^{24}$

The notion that Japan is a non-religious and religiously tolerant country overlooks the fact that Japan has a long history of regulating religious beliefs and suppressing and persecuting religious minorities whose "heretical" beliefs and practices challenged the state's authority, the Japanese polity, and the dominant polytheistic worldview. In the sixteenth and seventeenth centuries, Japan's decentralized provincial warring states were increasingly administered by the centralized government and this period also marked the beginning of the government's suppression of religious minorities who

\footnotetext{
${ }^{21}$ The Institute of Statistical Mathematics 2013.

${ }^{22}$ The JGSS Research Center at Osaka University of Commerce and the Institute of Social Science at The University of Tokyo 2016.

${ }^{23}$ Ama 2004, pp. 3-5.

${ }^{24}$ Inagaki 2002, p. 265.
} 
believed in a God, a transcendent being or reality more powerful than the state and rejected the state's absolute political power; Christianity was officially banned for more than 250 years from 1614 to 1873 and Nichiren-shü Fuju-fuse-ha 日蓮宗不受不施派 (“neither receiving nor giving," a sect of Nichiren Buddhism) was also severely suppressed for more than 200 years until $1876 .{ }^{25}$ It was during this period that the temple registration system became mandatory as part of the Tokugawa shogunate's attempt to suppress Christianity and Buddhist activities other than funerals and memorial services came to play less significant roles in people's daily lives.

When the Meiji government's attempt to purge "non-Japanese" Buddhist influences from "Japanese" Shinto and establish Shinto as a national religion largely failed in the 1870 s due to the lack of formal religious doctrine and missionaries among other reasons, the government combined Shrine Shinto with Imperial Household Shinto to establish Kokka Shinto 国家神道, State Shinto, making Shinto a religion of state rituals and a public morality. As part of the modernization and Westernization process in Japan, the government constructed a national identity that centered around the imperial institution by way of State Shinto, which, in the words of Isomae, was "essentially "invented tradition"' 26 rather than a modern revival of ancient traditions. It also granted official recognition to the thirteen independent Shinto sects as Kyōha Shinto 教派神道, Sect Shinto, and certain Buddhist and Christian sects or denominations, while cracking down on other religious minorities that challenged the state's or the emperor's authority and the national polity, particularly the "new religions," also referred to as "pseudo-religions" or "evil cults," one of the prominent examples being Ōmotokyō, and some Christian denominations, not only inside the main islands of Japan but also in its overseas colonies and occupied territories, and regulating religious groups with the Religious Organizations Law of 1939 during wartime. ${ }^{27}$ State Shinto was thus bureaucratized as a tradition above and beyond religion that belonged to the "secularized" public sphere, rather than the religious private sphere, which came to be formed as a result of the Western/Christian notion of the separation of religion and state that the Meiji government adopted, even though in reality the public sphere was imbued with state-sponsored religiosity. ${ }^{28}$ With the enactment of the Meiji Constitution in 1889 , which nominally recognized freedom of religion "within limits not prejudicial to peace and order, and not antagonistic to their duties as subjects," 29 the imperial Japanese government justified making Shinto shrine visits and emperor worship civic duties that continued until the end of World War II by emphasizing the non-religious nature of State Shinto so as to avoid being accused of violating the citizens' constitutional right to freedom of religion, although the government created the Board of Shinto Rites in 1940, which "formally elevated the authority of State Shinto over all other religions." 30

Even though the Shinto Directive that was issued in 1945 by Occupation authorities abolished State Shinto and the current Constitution that was enacted in 1946 provides for religious freedom and the separation of religion and state ${ }^{31}$ and prohibits the government from financially supporting any religious institution, ${ }^{32}$ conservative politicians in the post-war era still invoke the idea of Shinto as a tradition above and beyond religion that was propagated by the imperial Japanese government as a state ideology for militaristic and nationalistic purposes in their attempts to reunite Shinto and state. From 1969 to 1974, for example, the conservative Liberal Democratic Party (LDP) introduced bills to re-nationalize Yasukuni Shrine, the controversial Shinto shrine that commemorates Japan's war dead. Although the bills were not passed into law as they were met with resistance from the opposition parties as well as religious groups, including the Union of New Religious Organizations, prime

\footnotetext{
${ }^{25}$ Ibid., p. 267.

${ }^{26}$ Isomae 2014, p. xxii.

${ }^{27}$ Inagaki 2002, pp. 278-79.

${ }^{28}$ Isomae 2014, p. xxiii.

${ }^{29}$ MEIJI KENPō, art. 28.

${ }^{30}$ Garon 1986, p. 274.

${ }^{31} \mathrm{KENPō}$, art. 20.

${ }^{32} \mathrm{KENPō}$, art. 89.
} 
ministers have visited the shrine since 1976 and those who supported the reuniting of Shinto and state "maintained that the shrines were not religious but rather should be the sites of public rituals designed to foster a sense of belonging to the nation state." 33

As mentioned above, the level of trust in religious organizations is considerably low among the majority of Japanese people. This lack of trust in religious organizations can be partly attributed to the terrorist activities and crimes committed by members of the new religious movement or "cult" Aum Shinrikyō, the most heinous being the Tokyo subway sarin attack on March 20, 1995, which killed thirteen people and injured more than 6,000 people, making it "the largest incident of terrorism on Japanese soil in history and one of the most destructive disasters Japan has experienced in the postwar period." 34 Hardacre noted the tendency of the Japanese media's obsessive coverage of the Aum incident and the subsequent police investigation to "discipline" religion and the young for foolishly taking an interest in religion, that is, "to tar all religions with the same brush, insinuating that there is a need for greater supervision of all religions lest they go the way of Aum...evident in the frequent characterization of religion as 'hard to understand,' usually intoned with the implication that religion is alien, strange, and not something that ordinary people would be interested in," notwithstanding the fact that the Constitution guarantees religious freedom and many Japanese people do indeed take part in practices and rituals that have religious roots. ${ }^{35}$

The Religious Corporation Law of 1951, which replaced the Religious Organizations Law of 1939, along with the current Constitution protected the rights and freedoms of registered religious organizations from state intervention and interference and gave rise to "new religions," including those that were severely suppressed in the pre-1945 era. However, as Garon rightly points out, the 1995 Aum incident "brought the Japanese public's deep-seated anxieties about new religions to the surface" 36 and "did a great deal to soften postwar Japanese society's inhibitions against using state power to regulate religious organizations," ${ }^{37}$ which resulted not only in the dissolution of Aum as a religious corporation as stipulated in the Religious Corporation Law of 1951, but also in the revision of the said law in December 1995. The revision of the law was enacted with the support of the conservative LDP, the Socialist party, and the Communist party that wanted to curtail the political power of the new religions, the most prominent one being Sōka Gakkai and its political party Kōmeitō, notwithstanding the resistance from many religious organizations, especially the new religions, ultimately giving the government greater control over religious organizations.

It can be argued that the 1995 Tokyo subway sarin attack, among other terrorist activities and crimes committed by members of the new religious movement Aum Shinrikyō, reinforced distrust toward religious organizations among the Japanese public and gave the government greater control over such organizations. This, and the state power's extensive regulation of religion and persecution of religious minorities whose "heretical" beliefs and practices challenged the state's authority, the Japanese polity, and the dominant polytheistic worldview that continued until the end of World War II, have brought about to a considerable extent the depoliticization and privatization of religion, religious apathy, phobia of religion, and prejudice against people affiliated with a particular religious group among the general Japanese population, and paradoxically bolstered the notion that Japan is a non-religious and religiously tolerant country even with the postwar attempts to reunite Shinto and state.

\section{From religious apathy and phobia of religion to prejudice against Islam}

Although memories of Muslim-Japanese relations that flourished in the pre-war period seem to have faded in postwar Japan and Islam and Muslim communities remain relatively unknown to the general

\footnotetext{
${ }^{33}$ Garon 1997, p. 210.

${ }^{34}$ Hardacre 2007/2008, p. 171.

${ }^{35}$ Ibid., p. 199.

${ }^{36}$ Garon 1997, p. 211.

${ }^{37}$ Ibid., p. 212.
} 
Japanese public today, some major events have spurred national interest in Islam and Muslims. These events include the 9/11 attacks in 2001, the Charlie Hebdo shooting in early January 2015 in France, and the subsequent protests organized by Muslim groups, mainly consisting of Pakistanis, outside the headquarters of the Chunichi Shimbun Company in Tokyo against the Tokyo Shimbun's republication of Charlie Hebdo's cartoons of the Prophet Muhammad, which compelled the newspaper company to issue a letter of apology in their morning edition on January 29 for unintentionally offending Muslims. ${ }^{38}$ These were followed by the kidnapping and killing of two Japanese nationals by the Islamist extremist group, the so-called Islamic State (IS), in late January and early February 2015.

After 9/11, the Japanese police became vigilant against terrorism and targeted Muslims in their related investigation, sending undercover agents to mosques and Muslim gatherings, including weddings, to monitor their activities. ${ }^{39}$ In the days after 9/11, Sidiqqi notes that the number of Japanese Muslims coming to mosques decreased because they feared being associated with non-Japanese Muslims, who were in turn associated with terrorism. ${ }^{40}$ Following the IS killing of Japanese citizens in 2015, the United States Department of State's report noted that some Muslim organizations and mosques in Japan received harassing phone calls and that the police tightened security around Islamic facilities. ${ }^{41}$ In May 2016, the Supreme Court of Japan upheld the Tokyo High Court's April 2015 ruling, which awarded seventeen Muslim plaintiffs 90 million yen in total in compensation for invasion of privacy as over a hundred internal Metropolitan Police Department documents were leaked on the internet in October $2010 .^{42}$ The leaked documents revealed that the police had systematically monitored and surveilled Muslims in Japan before the Hokkaido Tōyako G8 Summit held in July 2008 and collected personal information, including bank account and passport details, of 72,000 Muslims who were labeled as (terrorist) "suspects." However, like the Tokyo High Court which upheld the Tokyo District Court's January 2014 ruling that the police's information gathering activities were "necessary and inevitable measures for the prevention of international terrorism," the Supreme Court found no violation of the constitutionally guaranteed rights to privacy, equality, and freedom of religion that resulted from the police profiling and surveillance of Muslims at mosques and other Islamic facilities. ${ }^{43}$ The Japan Times reported that "the Court ruling effectively gave the police a green light to continue surveillance of Japan's Muslims" and that police surveillance of Muslims is still happening, as of 2016, and children are no exception as they were also listed among the "suspects" and are treated like "potential homegrown terrorists." 44

With regard to the Japanese media's representations of Islam and Muslims, Sakai calls attention to problems with the ways in which the kidnapping and killing of two Japanese hostages by the Islamic State in January 2015 were reported. ${ }^{45}$ One of the problems that Sakai identifies is the Japanese media's prejudice against and lack of understanding of Islam, which became evident when the news outlets used the word Isurāmu koku イスラーム国, country of Islam, without adding the term kagekiha soshiki 過激派組織, extremist/militant group, and confused the Islamic State with an Islamic state (or a predominantly Islamic country), thereby perpetuating the stereotypical Orientalist understanding of Islam as an inherently violent religion, which in turn led the viewers to confuse extremists with the vast majority of Muslims who are not supportive of IS. ${ }^{46}$ Consequently, Muslim residents in Japan were harassed, mosques and embassies received complaints, and the Japanese media outlets started using the terms kagekiha soshiki Aiesu=Isuramikku sutēto, extremist group Islamic State, and

\footnotetext{
${ }^{38}$ Sato 2015, pp. $14-17$.

${ }^{39}$ Yamagishi 2008, p. 110.

${ }^{40}$ Siddiqi 2003, p. 165.

${ }^{41}$ The United States Department of State, Bureau of Democracy, Human Rights, and Labor, Japan 2016, p. 1.

${ }^{42}$ Ibid., p. 5.

${ }^{43}$ Takahashi 2018, pp. 204-06.

${ }^{44}$ Blakkarly 2016.

${ }^{45}$ Sakai 2015, pp. 68-71.

${ }^{46}$ Ibid., p. 69.
} 
Isuramu kagekiha soshiki “Isuramu koku," Islamic extremist group "Islamic State," after receiving requests from Muslim communities in Japan not to use the word Isurāmu koku alone.

Miura's study of the perceptions of Islam and Muslims among first-year high school and university students in post-9/11 Japan confirms Sakai's critique of the Japanese media's representations of Islam and Muslims. It shows that most students who answered the surveys he analyzed associated Islam with backwardness, aggressiveness, intolerance, peculiarity, strictness, and doctrinal rigidity as opposed to peace, charity, freedom, and progressiveness that were frequently associated with Christianity and Buddhism, the cause of which Miura partly attributes to media reports on Islam that mostly focus on wars and terror attacks among other political affairs and religious customs and practices that seem peculiar to Japanese people, and rarely show the daily lives of ordinary Muslims. ${ }^{47}$ Miura also attributes the cause of the students' biased knowledge of Islam and Muslims to secondary school textbooks that pertain to the Islamic world, which highlight the importance of Islamic civilization in the medieval period on the one hand but reinforce the peculiar image of Muslims in contemporary Muslim societies that has been constructed by the mass media on the other hand by emphasizing the all-encompassing nature and uniformity of Islam rather than its flexibility or cross-cultural adaptability. ${ }^{48}$ Thus, a lack of understanding about and prejudice against Islam continue to be normalized in Japanese society and the stereotypical portrayals of Islam and Muslims continue to dominate the media. ${ }^{49}$

As scholars have rightly pointed out, "ignorance and prejudice cultivated in the land of indifference,"50 "passive acceptance with indifference," ${ }^{51}$ and "indifference rather than tolerance" toward Islam and Muslims pervade Japanese society. ${ }^{52}$ To be sure, Islamophobia or prejudice against Islam in Japan is expressed in rather nuanced and subdued ways and Muslims in Japan may not regularly experience blatant discrimination on the basis of religion when compared with Europe and the United States. However, Japanese attitudes toward Islam and Muslims can hardly be characterized by "innocent" indifference: Islamophobic tendencies compounded with religious apathy and phobia of religion, along with ignorance, are manifested in the form of fictitious associations made between Islam and fundamentalism/extremism, and Muslims and terrorists that loom large in the Japanese national imaginary as evidenced by the media representations of Islam and Muslims that often instill a feeling of fear in viewers, and the profiling and surveillance of Muslims that is carried out by the police.

\section{The rhetoric of tabunka kyōsei and cosmetic multiculturalism}

In 2005, the Japanese government established the Research Group to Promote Multicultural Coexistence and published a report in March 2006, ${ }^{53}$ which outlined how tabunka kyōsei, multicultural coexistence, was to be realized locally through newcomers' communication support, livelihood support, and community development in cooperation with residents and civil society organizations and defined the term tabunka kyōsei as follows: "Where people of differing nationalities or ethnicities, etc., live together as constituent members of local society while forging equal relationships as they recognize each other's cultural differences." ${ }^{54}$ At first glance, the definition of the term tabunka kyōsei that recognizes cultural diversity seems unproblematic; however, there are several issues with this definition and the government's approach to immigration as critics have already pointed out that require attention. Yamashita, for example, notes that ethnically and culturally diverse "foreigners" are implicitly juxtaposed with the homogenous "Japanese" - after all, it is "Us" (Japanese) that must recognize

\footnotetext{
${ }^{47}$ Miura 2006, pp. 174-76.

${ }^{48}$ Ibid., p. 188.

${ }^{49}$ Katsura also speaks of a vicious cycle of prejudice against Islam and Islam-related incidents and its impact on Muslim individuals and communities in Japan. See Katsura 2020.

${ }^{50}$ Katakura 2004, p. 20.

${ }^{51}$ Yamagishi 2008, p. 102.

${ }^{52}$ Kawada 2004, p. 225.

${ }^{53}$ The Ministry of Internal Affairs and Communications 2006.

${ }^{54}$ Roberts 2013, p. 209.
} 
"Them" (foreigners) so as to respect each other's differences. ${ }^{55}$ The Japanese-foreigner binary that is constructed here is problematic because it reinforces the myth of a homogenous Japaneseness by conveniently ignoring internal differences and denying the fact that there are Japanese nationals with diverse cultural heritages who may or may not pass as Japanese. In addition, the essentialized notion of "culture" as conceived by the government presupposes distinct cultural groups with fixed cultural practices and assumes that there is such a thing as one "Japanese culture" or "Islamic culture" and such essentialist concept of culture often limits cross-cultural understanding to the so-called 3F (Fashion, Festival, Food) initiatives of superficial or cosmetic multiculturalism. ${ }^{56}$

As will be shown below, Islam in Japan is often perceived as one homogenized "culture," which has proven problematic when local governments implement tabunka kyōsei measures beyond setting up prayer rooms and making halal food options for tourists. Tanada found that, for instance, some local governing bodies that maintain certain levels of communication with mosques have faced difficulties in implementing tabunka kyōsei measures for Muslim residents, such as setting up prayer rooms and accommodating dietary restrictions for events, because mosques (and other Muslim organizations) in Japan are multiethnic and diverse, meaning Muslims themselves hold different opinions about Islamic beliefs and practices and have difficulties coming to an agreement on certain religious rules. ${ }^{57}$ Some Muslims may not agree to participate in mixed-gender events or use mixed-gender prayer rooms; some may not consider dishes halal (permissible for consumption) if they are prepared in the kitchen that is used to cook dishes that contain alcohol or pork-derived ingredients, whereas others simply consider non-pork dishes as halal.

Morris-Suzuki has referred to Japan's version of multiculturalism as superficial multiculturalism or cosmetic multiculturalism. ${ }^{58}$ She identifies four conditions under which national identity that promotes "desirable" cultural diversity is expressed under the regime of cosmetic multiculturalism: diversity must fit within a narrowly defined space of "culture" which refers to the esthetic, detached from politics and the ordinary; it must be displayed in a manageable form or space such as music performance at a festival as part of a summit meeting; it must be limited to a superficial, decorative form that does not challenge the power relations that operate within the existing social structure; and lastly, those who do not pass as Japanese must visibly display their loyalty to Japan in order for cultural diversity to be recognized. ${ }^{59}$ The following sections will show that Islam in Japan tends to be presented and tolerated as (foreign) "culture," especially within the framework of tabunka kyōsei, multicultural coexistence, rather than a religion that is practiced and performed in various ways by people from diverse backgrounds, including Japanese people, and that the cosmetic multiculturalist understanding of "culture" is applied to "Islamic culture."

\section{Islam as (foreign) "culture"}

\section{Local oppositions to the construction of mosques}

Local residents have voiced opposition to the construction of mosques in various parts of Japan. In 2006, Fukuoka Mosque faced opposition from local residents who associated Islam with fundamentalism, sectarianism, and wars when it became apparent that Muslims bought land near Hakozaki Station to build a mosque. The Mainichi Shimbun reported that after Muslim international students from Kyushu University and a Japanese Muslim, who acted as a negotiator between Muslims and local residents, had more than ten meetings with the residents' association to explain the basic teachings of Islam and show how the daily prayers are performed, they came to an agreement in December 2007 to

\footnotetext{
${ }^{55}$ Yamashita 2010, p. 331.

${ }^{56}$ Ibid., pp. 331-32.

${ }^{57}$ Tanada 2019b, p. 231.

${ }^{58}$ Morris-Suzuki 2013, pp. 183-84.

${ }^{59}$ Ibid., pp. $184-85$.
} 
allow the mosque to be built on condition that the mosque-goers assign on-site staff, participate in community activities, including cleaning, and do not make noise or park their cars. ${ }^{60}$

Ishikawa Muslim Society (IMS), which mainly consists of international students at Kanazawa University, was also met with resistance from local residents in September 2011 when they explained to residents in the neighborhood that they were building a mosque in a residential area of Kanazawa City. The Yomiuri Shimbun reported that the residents who opposed the building project remarked that locals felt uneasy about having a mosque built in their neighborhood as they expressed concern about Islam and Muslim in relation to terrorism, suspected that it might trigger incidents that target Muslims as it happened in the neighboring prefectures and they were also worried about practical issues such as noise, parking and appearance of the building. Matsui Satoshi, the vice president of IMS, who is a Japanese Muslim, explained that Islam did not condone terrorism or suicide but biased information on Islam available in Japan caused people to think otherwise. ${ }^{61}$ Although the municipal regulations did not require the residents' approval in acquiring building permission from the city office, IMS chose to continue their discussion and negotiation with the residents' association until they reached an agreement in August 2012 to allow Kanazawa Mosque to be built as mosque-goers agreed to meet the residents' demands by taking out the garbage at a designated time and place, shoveling the snow and not making noise. The vice president of IMS noted that the mosque will be open to non-Muslim residents by introducing "Islamic culture" and offering cooking classes so that their relationship and the residents' understanding of Muslims can be improved, reported the Mainichi Shimbun. ${ }^{62}$

Similarly, Toyama Muslim Students Community whose members are mainly international students at the University of Toyama, had to abandon their plan to build a mosque in Gofuku in Toyama City in the winter of 2012 as they were met with local opposition, but were able to open the Toyama Muslim Center (TMC), a mosque-cum-cultural exchange facility in June 2014. As with Kanazawa Mosque, the TMC members agreed to abide by community rules regarding parking, garbage disposal and community bulletin board, and also to participate in community activities and utilize the facility as a place for international students to interact with local residents. ${ }^{63}$

The Shizuoka Masjid Project was initiated in 2013 by Shizuoka Muslim Association with the aim of building a Japanese-style mosque along with Islamic Culture Center in Shizuoka City, Shizuoka Prefecture by 2020 before the Tokyo Olympics. The Shizuoka Shimbun reported that, as with the preceding cases, the Shizuoka Masjid Project was also faced with opposition from local residents at an information session that was held in August 2017, even though the association had received approval from the neighborhood association's executive members to build a mosque on the land they purchased in 2017. ${ }^{64}$ Despite opposition, Asadi Yasin, the representative of Shizuoka Muslim Association who is originally from Morocco, and his wife and secretariat Asadi Miwa, a Japanese Muslim, said that they were committed to continue negotiations with the local residents and participate in community events as they planned to build a mosque that was open to the general public with a library, kitchen, accommodation facility, and a tsunami evacuation tower, which they hoped would facilitate interaction between visitors from abroad and both Muslim and non-Muslim local residents of Shizuoka and improve non-Muslims' understanding of "Islamic culture." ${ }^{65}$ The Shizuoka Masjid Project was completed and a private view of the mosque was held on October 10, 2019 and a cultural exchange event was held at the end of the month where visitors got to take a tour around the mosque and experience fashion of the Muslim world. ${ }^{66}$ At the private view, the secretariat mentioned that she hopes the

\footnotetext{
${ }^{60}$ Mikazuki to hoshi no tonaribito: Hakozaki mosuku o meguru hitobito Nihonjin Musurimu sesshō yakuni 2008.

${ }^{61}$ Jimoto hanpatsu kennai hatsu Kanazawa ni chōkai Isuramu bunka ni gimon ya fuan 2011.

${ }^{62}$ Ishikawa Musurimu Kyōkai: Mosuku kensetsu keikaku de gōi rikai fukamaru kōryū o-Kanazawa, Wakamatsu chōkai 2012.

${ }^{63}$ Isuramu gakusei ni yoru kōryū shisetsu Toyama ni jūmin otozure iken kōkan 2014.

${ }^{64}$ Mochimune ni kōryū no mosuku o Shizuoka Musurimu Kyōkai, minato kinsetsuchi shutoku 2017.

${ }^{65}$ Chūko jūtaku, purehabu-Nihon no 'mosuku' to Isuramu shakai 2017.

${ }^{66}$ Musurimu reihaidō kansei: Suruga-ku ‘Shizuoka Masujido’ 2019.
} 
mosque will “contribute to Shizuoka's tabunka kyōsei [multicultural coexistence] and community revitalization, adding value and presence." ${ }^{\prime 6}$

The above cases of building projects of mosques share certain common characteristics. First, some local residents expressed concern about and prejudice against Islam and Muslims, associating them with fundamentalism and seeing them as a potential cause of community problems, whereas others were more concerned about practical issues such as noise, appearance, and community rules regarding parking and garbage disposal. Second, rather than taking legal action, the Muslim organizations which led the building projects decided to continue negotiations with the local residents to foster better relationships with them and a better understanding of Islam, and Japanese Muslims acted as negotiators between Muslims and local residents, despite - or perhaps because of - the lack of regulatory issues involved in the construction of the mosques. Third, to dissociate Islam from terrorism/extremism, alleviate religious apathy, phobia of religion, and prejudice against Islam, present themselves in a way that is more "acceptable" to the Japanese, and facilitate better communication with the neighbors, the Muslim organizations "culturalized" Islam or emphasized the cultural aspects of Islam and decided to open their mosques to the general public as cultural exchange facilities where international students/visitors can interact with non-Muslim Japanese neighbors.

\section{Participant observation at events organized by Muslim groups in Japan}

Islamic cultural exchange event (June 2, Ramadan 2018)

During Ramadan 2018, I participated in Islamic Cultural Exchange Event which was organized by the Indonesian Muslim Association in Japan at Tokyo Indonesian School on June 2. The purpose of the cultural exchange event at Tokyo Indonesian School, according to the event pamphlet, was for people to experience Islam through the following sub-events: a lecture given by a Japanese imam, Ahmad Maeno, who is fluent in Arabic and English and received his religious training in Syria; a talk show/panel discussion between imam Maeno, Jahangir Mujahed, an Italian restaurant owner, and Aufa Yazid, a female Muslim content creator; traditional Indonesian dance and martial arts performances; a Muslim fashion, including the hijāb and henna, try-on booth; an Arabic calligraphy booth; a tour around Masjid Indonesia, a mosque that was built on the school premise in the summer of 2017; and lastly, an Iftar, which is the evening meal that is taken at sunset every day during Ramadan. A Muslim woman of Japanese and Indonesian origins who was at the Muslim fashion try-on booth, where non-Muslim women were invited to wear different types of hijābs, highlighted the practical aspects of hija $b$ and told me how the hija $\bar{b}$ is just like the sun-protective clothing worn by some Japanese women covering the whole body, sometimes even the face, that protects one from intense sunlight in the summer and how it also keeps one warm during the winter.

Another Muslim woman of Indonesian origin, who was born and raised in Tokyo, shared her experience of wearing the hijāb in Japan during the talk show. She related that while Muslim women typically start wearing the headscarf when they reach pubescence, she waited until she entered university because she wore school uniforms in middle and high school and did not want to be different from other Japanese students and her mother did not push her to wear one until she was ready. She commented how she realized that Muslim women can be creative and fashionable with their hijāb just like any other woman, play with makeup and different styles and colors of clothing, and match the hijäb with Japanese-style clothes as long as they follow the basic rule of covering their 'awra ("nakedness" in Arabic, which typically refers to a woman's body except the face, hands and feet that must not be seen by non-mahrams, that is, men with whom marriage is considered permissible, although it is open to different interpretations). Some fashion, practical, and ethical aspects of the hija $b$ were emphasized at the event so as to familiarize non-Muslim Japanese people with the practice of wearing the hijäb and the basic teachings of Islam that are also shared by Japanese cultural norms. The purpose

\footnotetext{
${ }^{67}$ Isuramu kyōkai mosuku nairankai: Shizuoka, 'tabunka kyōsei e sonzaikan’ 2019.
} 
of Cultural Exchange Event at Tokyo Indonesian School, it seemed, was to alleviate non-Muslim Japanese people's religious apathy, phobia of religion and negative perceptions they may have of Islam by "culturalizing" Islam or presenting certain aspects of Islam as "Islamic culture" as it was similarly observed during the building projects of mosques as mentioned previously.

\section{Tokyo Islamic cultural exchange festival (August 11, Eid al-Adha 2019)}

I also attended Tokyo Islamic Cultural Exchange Festival at a park in Minato-ku on August 11, 2019 during the Eid al-Adha weekend, which was organized by the Tokyo Islamic Cultural Exchange Festival Committee and supported by Chiba Islamic Cultural Center and Nippon Asia Halal Association, the Ministry of Foreign Affairs of Japan and the Tokyo Metropolitan Government. The purpose of the event, according to the event website, was to introduce food cultures of Islamic countries and other elements of "Islamic culture" so as to promote international exchange and friendship between Japanese people and foreigners. There were about twenty food trucks that sold Turkish, Bangladeshi, and Indonesian dishes along with other kinds of halal food that practically surrounded the event venue.

Aside from food, there was an Indonesian religious music performance, a lecture on "Islam in the West," a prayer workshop for peace, an Islamic quiz for children, a halal cooking workshop, a booth that handed out free copies of the recently published Japanese translation of the Qur'an, and other participatory cultural activities, including an Arabic calligraphy booth, a hijāb and henna try-on booth, and a Q\&A session about Islam. I only saw a sparse crowd at the event during the time I was there from noon until evening and most people were gathered around the food trucks; I did not see any form of "international exchange and friendship between Japanese people and foreigners" that the event was supposed to promote, except for a few visitors who were talking with Muslims at the booths for cultural activities. As with the previous event, it seemed that "cultural" aspects of Islam, that is, the $3 \mathrm{~F}$ (Fashion, Festival, Food) cultures, were brought to the fore while religious elements remained in the background. It might very well be the case that the event organizers intentionally emphasized the cultural aspects of Islam so as to present themselves in a way that was "acceptable" to the Japanese, the vast majority of whom feel apathetic toward and prejudiced against religion and Islam, to facilitate better communication between "the Japanese" and "foreigners," and to foster a better understanding of Islam and Muslims along the way.

To summarize my observations, the $3 \mathrm{~F}$ aspects of what is touted as "Islamic culture" were particularly emphasized at both events organized by Muslim groups as they were centered around cultural activities, including fashion try-on booths/workshops, dance/music performances, and halal food trucks and cooking workshop. Granted, these events also featured Islamic lectures and other educational segments but these religious elements remained in the background for the most part whereas cultural aspects were brought to the fore as is also indicated by the titles of the events that I participated in: "Islamic Cultural Exchange Event" and "Tokyo Islamic Cultural Exchange Festival." Adopting the tabunka kyōsei rhetoric and culturalizing Islam or presenting certain aspects of Islam as "Islamic culture" has been a strategic way for Muslim groups, so it seems, to alleviate non-Muslim Japanese people's religious apathy, phobia of religion, and negative perceptions or misconceptions they may have of Islam by "taming" the image of Islam and Muslims in ways that are "acceptable" to the Japanese and fostering a better understanding of Islam and international/cultural exchange between the Japanese and Muslims (who are often assumed to be foreigners).

\section{Conclusion}

In this paper, I have presented a history of Muslim-Japanese relations and Muslim communities in Japan along with an overview of the total estimate of the Muslim population in Japan as of 2018, historicized and denaturalized religious apathy, phobia of religion, and prejudice against Islam among the general Japanese public, then analyzed the rhetoric of tabunka kyosei that perpetuates the myth of a homogenous Japaneseness, discussed Morris-Suzuki's concept of cosmetic multiculturalism, and 
finally I have demonstrated, based on the cases of local oppositions to the building projects of mosques and my observations made at the events organized by Muslim groups, that Islam in Japan is often tolerated as (foreign) "culture," especially within the framework of tabunka kyōsei, and is "culturalized" or presented as "Islamic culture" to alleviate religious apathy, phobia of religion, and prejudice against Islam.

I argue that the $3 \mathrm{~F}$ initiatives and the cosmetic multiculturalist approach to tabunka kyōsei adopted by some Muslim organizations and local governing bodies are, to a certain extent, mutually beneficial to both Muslims and non-Muslim Japanese people. Communication between both parties is facilitated to some degree and non-Muslims' understanding of "Islamic culture," however superficial it may be, is improved. Nonetheless, Islam cannot be thought of as one homogenized culture: Muslim communities in Japan are culturally and religiously diverse and the levels of religious observance vary from generation to generation and person to person. Furthermore, the cosmetic multiculturalist understanding of "culture" that is applied to "Islamic culture" is detached from politics and the ordinary, presented in a manageable form or space, limited to the esthetic, superficial, or decorative that does not challenge the norms and power relations within the social structure and even requires one to display loyalty to Japan. I argue that such a limited understanding of Islam as (foreign) "culture" does not resolve everyday issues that are faced by some Muslims, including Japanese Muslims who lack the so-called gaikokujin-sei 外国人性, foreignness, as scholars have already mentioned. When non-Japanese Muslims perform the daily prayers and wear the hijāb, they are tolerated because they are perceived to be foreigners and these practices are considered to be a part of their (foreign) culture whereas Japanese Muslims performing the same religious practices are often seen either as foreigners or "strange people" who are merely imitating the ethnic customs of Middle Eastern or Southeast Asian Muslims as they challenge the norms within Japanese society and destabilize the Japanese-foreigner binary, which often makes it more difficult for them to negotiate their Muslimness and Japaneseness than their non-Japanese counterparts. ${ }^{68}$ In effect, religious accommodations for prayers, dietary restrictions, fasting, and clothing are more likely to be provided in Japanese schools and workplaces when requests are made by non-Japanese Muslims since Islam as culture, rather than a religion, can be tolerated within the framework of cultural exchange or tabunka kyōsei, avoiding reference to the (narrow interpretation of) religious neutrality and secularity that currently prevails in public institutions. ${ }^{69}$

Although the Muslim population in Japan is still relatively small, the number of Muslim permanent residents, migrant workers, students, Japanese converts, naturalized Japanese Muslims, second- and third-generation Muslims is expected to continue to increase. Many migrant workers will undoubtedly continue to come from Muslim-majority countries with the revised Immigration Control and Refugee Act that came into force on April 1, 2019 by which the Japanese government officially opened the door to the so-called low-skilled foreign workers. I would argue that now is the time to move beyond the level of performative tolerance and cosmetic multiculturalism. Rather than reducing Islam to an undifferentiated "culture," and by implication, their (foreign) culture, due attention needs to be given to the fact that Islam is a religion that is practiced and performed in various ways by people from diverse backgrounds, including Japanese people. The essentialist concept of culture and the notion of a homogenous Japanese national identity that prevail in the tabunka kyōsei rhetoric need to be challenged and the arbitrarily and ambiguously demarcated boundary between "foreigners" and "the Japanese" needs to be undrawn and reworked so that the multiplicity of differences and identities among Japanese nationals and Muslims can be recognized and respected.

Acknowledgment. I would like to thank the two anonymous reviewers and the editors of IJAS for critically reading the earlier drafts of this manuscript and providing insightful comments.

\footnotetext{
${ }^{68}$ Kawada 2004, pp. 179-80; Komura 2015, p. 154; Kudo 2008, pp. 188-89; Sato 2015, p. 67.

${ }^{69}$ Komura 2015, pp. 104-05; Sato 2015, p. 206.
} 


\section{References}

Ama, Toshimaro (2004). Why Are the Japanese Non-Religious? Lanham: University Press of America.

Ando, Junichiro 安藤潤一郎 (2014). “Nihon senryōki no kahoku ni okeru Chugoku Kaikyō Sōrengōkai no setsuritsu to Kaimin shakai-Nitchū Sensōki Chugoku no 'minzoku mondai’ ni kansuru jirei kenkyū e mukete.”日本占領下の華 北における中国回教総聯合会の設立と回民社会一日中戦争期中国の「民族問題」に関する事例研究へ向けて. Journal of Asian and African Studies 87, pp. 21-81.

Asad, Talal (2003). Formations of the Secular: Christianity, Islam, Modernity. Stanford: Stanford University Press.

Aydin, Cemil (2007). The Politics of Anti-Westernism in Asia: Visions of World Order in Pan-Islamic and Pan-Asian Thought. New York: Columbia University Press.

Blakkarly, Jarni (2016). “Shadow of Surveillance Looms over Japan's Muslims.” Japan Times, July 13. https://www.japantimes.co.jp/community/2016/07/13/issues/shadow-surveillance-looms-japans-muslims/\#.XIAH_i2B1sP.

Brandenburg, Ulrich (2020). “Imagining an Islamic Japan: Pan-Asianism's Encounter with Muslim Mission.” Japan Forum 32:2, pp. 161-84.

Chūko jūtaku, purehabu-Nihon no 'mosuku’ to Isuramu shakai 中古住宅、プレハブー日本の「モスク」とイスラ 厶社会 (2017). Yahoo! News, Oct. 12. https://news.yahoo.co.jp/feature/773.

Esenbel, Selçuk (2011). “Japan's Global Claim to Asia and the World of Islam: Transitional Nationalism and World Power, 1900-1945.” In Japan, Turkey and the World of Islam: The Writings of Selçuk Esenbel, Vol. 3, pp. 1-27. Folkestone: Global Oriental.

Garon, Sheldon M. (1986). “State and Religion in Imperial Japan, 1912-1945.” Journal of Japanese Studies 12:2, pp. 273-302.

Garon, Sheldon M. (1997). Molding Japanese Minds: The State in Everyday Life. Princeton: Princeton University Press.

Green, Nile (2013). "Shared Infrastructures, Informational Asymmetries: Persians and Indians in Japan, c. 1890-1930." Journal of Global History 8, pp. 414-35.

Haddad, Yvonne Yazbeck, Jane I. Smith and Kathleen M. Moore (2006). Muslim Women in America: The Challenge of Islamic Identity Today. New York: Oxford University Press.

Hardacre, Helen (2007/2008). "Aum Shinrikyō and the Japanese Media: The Pied Piper Meets the Lamb of God." History of Religions 47:2/3, pp. 171-204.

Higuchi, Mimasaka 樋口美作 (2007). Nihonjin Musurimu to shite ikiru 日本人ムスリムとして生きる. Tokyo: Kōsei Shuppansha.

Higuchi, Naoto 樋口直人, Inaba Nanako 稲葉奈々子, Tanno Kiyoto 丹野清人, Fukuda Tomoko 福田友子 and Okai Hirofumi 岡井宏文 (2007). Kokkyō o koeru一Tainichi Musurimu imin no shakai gaku 国境を越える一滞日ム スリム移民の社会学. Tokyo: Seikyūsha.

Inagaki, Hisakazu 稲垣久和 (2002). “Nihon no shūkyō jōkyō ni okeru ōyake to watakushi to kōkyōsei.” 日本の宗教状況に おける公・私と公共性. In Nihon ni okeru ōyake to watakushi 日本における公と私, eds. Sasaki Takeshi and Kim Taishō, pp. 265-91. Tokyo: University of Tokyo Press.

Ishikawa Musurimu Kyōkai: Mosuku kensetsu keikaku de gōi rikai fukamaru kōryū o-Kanazawa, Wakamatsu chōkai 石川ムスリム協会：モスク建設計画で合意理解深まる交流を一金沢、若松町会 (2012). Mainichi Shimbun Ishikawa, Aug. 23.

Isomae, Jun'ichi (2014). Religious Discourse in Modern Japan: Religion, State, and Shinto, trans. Galen Amstutz and Lynne E. Riggs. Leiden: Brill Academic Publishers.

Isuramu gakusei ni yoru kōryū shisetsu Toyama ni jūmin otozure iken kōkan イスラム学生による交流施設 富山に住 民訪れ意見交換 (2014). Halal Japan, July 4. https://halaljapan.jp/halalnews140704-1281.html.

Isuramu kyōkai mosuku nairankai: Shizuoka, ‘tabunka kyōsei e sonzaikan’イスラム協会モスク内覧会静岡、「多 文化共生一存在感」 (2019). Shizuoka Shimbun, Oct. 11. https://www.at-s.com/news/article/topics/shizuoka/691887.html.

Jimoto hanpatsu kennai hatsu Kanazawa ni chōkai Isuramu bunka ni gimon ya fuan 地元反発 県内初金沢に町会イス ラム文化に疑問や不安 (2011). Yomiuri Shimbun, Oct. 4.

Kanayama, Saho 金山佐保 (2011). "Shōgaigaku×Nihonjin Musurimu=?-Shōgaigaku ni kōken shitai, mōhitotsu no mainoritiikō.”障害学×日本人ムスリム=?一障害学に貢献したい、もう一つのマイノリティ考. Shōgaigaku Kenkyū 7, pp. 335-38.

Katakura, Motoko 片倉もとこ (2004). “Nihon shakai to Isurāmu o megutte.”日本社会とイスラームをめぐって. In Isurāmu sekai イスラーム世界, eds. Katakura Motoko, Umemura Hiroshi and Shimizu Yoshimi, pp. 2-20. Tokyo: Iwanami Shoten.

Katsura, Yusuke 桂悠介 (2020). “Konvājon kenkyū o tōshita kyōsō no kanōsei-Nihon no shuryū shakai to Isurāmu no kankei o toraeru shuppatsuten to shite.”コンヴァージョン研究を通した共創の可能性一日本の主流社会とイス ラームの間関係を捉える出発点として. Mirai Kyōsō 7, pp. 161-92.

Kawada, Naoko 河田尚子 (2004). Nihonjin josei shinto ga kataru Isurāmu annai 日本人女性信徒が語るイスラーム案内. Tokyo: Tsukubanesha.

Kawada, Naoko 河田尚子, ed. (2011). Isurāmu to josei イスラームと女性. Tokyo: Kokusho Kankōkai.

Kobayashi, Yasuko 小林寧子 (2006). “Isurāmu seisaku to senryōchi shihai.” イスラーム政策と占領地支配. In Iwanami kōza Ajia Taiheiyō sensō: Shihai to bōryoku 岩波講座アジア・太平洋戦争：支配と暴力, Vol. 7, eds. Kurasawa Aiko, 
Sugihara Toru, Narita Ryuichi, Tessa Morris-Suzuki, Yui Daizaburo and Yoshida Yutaka, pp. 63-94. Tokyo: Iwanami Shoten.

Komai, Hiroshi 駒井洋 (2004). “Nihon no Musrimu shakai o aruku.” 日本のムスリム社会を步く. In Isurāmu sekai イス ラーム世界, eds. Katakura Motoko, Umemura Hiroshi and Shimizu Yoshimi, pp. 198-212. Tokyo: Iwanami Shoten.

Komura, Akiko 小村明子 (2015). Nihon to Isurāmu ga deau toki-Sono rekishi to kanōsei 日本とイスラームが出会うと き—その歴史と可能性. Tokyo: Gendai Shokan.

Komura, Akiko 小村明子 (2019). Nihon no Isurāmu一Rekishi, shūkyō, bunka o yomitoku 日本のイスラーム一歴史・宗 教・文化を読み解く. Tokyo: Asahi Shimbun Publications.

Kudo, Masako 工藤正子 (2008). Ekkyō no jinruigaku-Zainichi Pakisutanjin Musurimu imin no tsuma tachi 越境の人類 学一在日パキスタンムスリム移民の妻たち. Tokyo: University of Tokyo Press.

Kurasawa, Aiko 倉沢愛子 (1981). “Dōin to tōsei-Nihongunseiki no Jawa ni okeru Isuramu senbu kōsaku ni tsuite.” 動員と 統制一日本軍政期のジャワにおけるイスラム宣撫工作について． Southeast Asia: History and Culture 10, pp. 69-121.

Matsunaga, Akira 松長昭 (2008). “Tokyo Kaikyō Danchō Kurubangarii no tsuihō to Isurāmu seisaku no tenkai.” 東京回教 団長クルバンガリーの追放とイスラーム政策の展開. In Nitchū Sensō to Isurāmu: Manmō Ajia chiiki ni okeru tōchi kaijyu seisaku 日中戦争とイスラーム—満蒙・アジア地域における統治・懷柔政策, ed. Sakamoto Tsutomu, pp. 179-232. Tokyo: Keio Gijuku Daigaku Shuppankai.

Mikazuki to hoshi no tonaribito: Hakozaki mosuku o meguru hitobito Nihonjin Musurimu sesshō yakuni 三日月と星 の隣人: 箱崎・モスクを巡る人々 日本人ムスリム折衝役に (2008). Mainichi Shimbun Fukuoka, June 26.

Miki, Hizuru 三木英 and Numajiri Masayuki 沼尻正之 (2012). “Musurimu to deau Nihon shakai.”ムスリムと出会う日 本社会. In Nihon ni ikiru imin tachi no shūkyō seikatsu一Nyūkamā no motarasu shūkyō tagenka 日本に生きる移民たち の宗教生活一ニューカマーのもたらす宗教多元化, eds. Miki Hizuru and Sakurai Yoshihide, pp. 225-51. Kyoto: Minerva Shobō.

Misawa, Nobuo and Göknur Akçadağ (2007). "The First Japanese Muslim, Shōtarō Noda (1868-1904)." Annals of Japan Association of Middle East Studies 23:1, pp. 85-109.

Miura, Toru (2006). "Perceptions of Islam and. Muslims in Japanese High Schools: Questionnaire Survey and Textbooks." Annals of Japan Association of Middle East Studies 21:2, pp. 173-91.

Mochimune ni kōryū no mosuku o Shizuoka Musurimu Kyōkai, minato kinsetsuchi shutoku 用宗に交流のモスクを 静岡ムスリム協会、港近接地取得 (2017). Shizuoka Shimbun, July 15.

Morris-Suzuki, Tessa (2013). Hihanteki sōzōryoku no tameni: Grōbaruka jidai no Nihon 批判的想像力のために一グロー バル化時代の日本, trans. Ito Shigeru. Tokyo: Heibonsha.

Musurimu reihaidō kansei: Suruga-ku 'Shizuoka Masujido’ムスリム礼拝堂完成 駿河区「静岡マスジド」(2019). Chūnichi Shimbun, Oct. 11. https://www.chunichi.co.jp/article/shizuoka/tokai-news/CK2019101102100008.html.

Omoso, Chisako 重親知左子 (2005). “Shūkyō dantaihō o meguru kaikyō kōnin mondai no haikei.” 宗教団体法をめぐる 回教公認問題の背景. Osaka Daigkau Gengo Bunka Gaku 14, pp. 131-44.

Roberts, Glenda S. (2013). "Vocalizing the 'I' Word: Proposals and Initiatives on Immigration to Japan from the LDP and Beyond." Journal of Asia-Pacific Studies 19, pp. 201-19.

Said, Edward W. (1997). Covering Islam: How the Media and Experts Determine How We See the Rest of the Word. Rev. ed. London: Vintage.

Sakai, Keiko 酒井啓子 (2015). “Kokusaihōdō to kōkyōhōsō-Isurāmu hōdō kara kangaeru.” 国際報道と公共放送一イス ラーム報道から考える. Gakujutsuno Dōkō 20:12, pp. 68-71.

Sakamoto, Tsutomu 坂本勉 (2008). “Abudyurureshito Iburahimu no sairainichi to Mōkyō seiken ka no Isurāmu seisaku." アブデュルレシト・イブラヒムの再来日と蒙疆政権下のイスラーム政策. In Nitchū Sensō to Isurāmu: Manmō Ajia chiiki ni okeru tōchi kaijyū seisaku 日中戦争とイスラーム—満蒙・アジア地域における統治・懷柔政策, ed. Sakamoto Tsutomu, pp. 1-81. Tokyo: Keio Gijuku Daigaku Shuppankai.

Sakurai, Keiko 桜井啓子 (2003). Nihon no Musurimu shakai 日本のムスリム社会. Tokyo: Chikuma Shobō.

Sato, Kenei 佐藤兼永 (2015). Nihon no naka de Isuramukyōo shinjiru 日本の中でイスラム教を信じる. Tokyo: Bungei Shunjū.

Shimada, Daisuke 島田大輔 (2015). “Shōwa senzenki ni okeru kaikyō seisaku ni kansuru kōsatsu一Dai Nippon Kaikyō Kyōkai o chūshin ni.” 昭和戦前期における回教政策に関する考察：大日本回教協会を中心に [Consideration of the Islamic Policy in Wartime Japan: Focus on the Dai Nippon Kaikyo Kyokai]. Isshinkyō Sekai (March), pp. 64-86.

Shimizu, Hiroshi (2005). “The Indian Merchants of Kobe and Japan's Trade Expansion into Southeast Asia Before the Asia-Pacific War.” Japan Forum 17:1, pp. 25-48

Siddiqi, Muhammad Abdul Rahman (2003). “Mosuku no genjō to tenbō.”モスクの現状と展望, trans. Kadotani Takako. In Tabunka shakai e no michi 多文化社会への道, ed. Komai Hiroshi, pp. 142-72. Tokyo: Akashi Shoten.

Sugita, Hideaki (2007). “The First Contact between Japanese and Iranians as Seen through Travel Diaries.” In The Islamic Middle East and Japan: Perceptions, Aspirations, and the Birth of Intra-Asian Modernity, ed. Renée Worringer, pp. 11-31. Princeton: Markus Wiener Publishers. 
Takahashi, Saul J. (2018). “Muslim Surveillance in Japan: A Narrative Aimed at Trivialization." Islamophobia Studies Journal 4:2, pp. $195-209$.

Tanada, Hirofumi 店田廣文 (2015). Nihon no mosuku一Tainichi Musurimu no shakai teki katsudō 日本のモスク一滞日 ムスリムの社会的活動. Tokyo: Yamakawa Shuppansha.

Tanada, Hirofumi 店田廣文 (2018). "Nihonjin Musurimu towa dare no kotoka-Nihon ni okeru Isurāmukyōto (Musurimu) jinkō no genzai.”日本人ムスリムとは誰のことか一日本におけるイスラーム教徒（ムスリム）の人 口の現在. Shakaigaku Nenshi 59, pp. 109-28.

Tanada, Hirofumi 店田廣文 (2019a). “Sekai to Nihon no Musurimu jinkō 2018 nen.”世界と日本のムスリム人口 2018 年. Ningenkagaku Kenkyū 32:2, pp. 253-62.

Tanada, Hirofumi 店田廣文 (2019b). “Chihō jichitai ni okeru Musurimu jūmin ni taisuru 'tabunka kyōsei' shisaku no genjō.”地方自治体におけるムスリム住民に対する「多文化共生」施策の現状. Ningenkagaku Kenkyu 32:2, pp. 225-34.

Terada, Kimiyo 寺田貴美代 (2004). Kyōsei shakai to mainoritii e no shien-Nihonjin Musurima no shakai teki taiō kara 共 生社会とマイノリティへの支援一日本人ムスリマの社会的対応から. Tokyo: Tōshindō.

The European Commission against Racism and Intolerance (2015). General Policy Recommendation No. 15, On Combating Hate Speech. Dec. 8. https://rm.coe.int/ecri-general-policy-recommendation-no-15-on-combating-hatespeech/16808b5b01.

The Institute of Statistical Mathematics (2013). “The Survey on the Japanese National Character.” https://www.ism.ac.jp/ kokuminsei/en/index_e.html.

The JGSS Research Center at Osaka University of Commerce and the Institute of Social Science at The University of Tokyo (2016). "Japanese General Social Surveys 'JGSS-2012'.” The Social Science Japan Data Archive, Center for Social Research and Data Archives, Institute of Social Science, The University of Tokyo, Oct. 12.

The Ministry of Internal Affairs and Communications (2006). Tabunka kyōsei no suishin ni kansuru kenkyūkai hōkokusho —Chiiki ni okeru tabunka kyōsei no suishin ni mukete 多文化共生の推進に関する研究会報告書一地域における多 文化共生の推進に向けて. Mar. 5. http://www.soumu.go.jp/kokusai/pdf/sonota_b5.pdf.

The United Nations, Department of Economic and Social Affairs, Population Division (2019). World Population Prospects 2019. https://population.un.org/wpp/.

The United States Department of State, Bureau of Democracy, Human Rights, and Labor. Japan 2016 International Religious Freedom Report. https://www.state.gov/wp-content/uploads/2019/01/Japan-3.pdf.

Trispiotis, Illias (2017). "Islamophobia in European Human Rights Law." Working paper no. 1, Rights, Equality and Citizenship (REC) Programme of the European Union, July.

Usmanova, Larisa (2006). "Senzen no Higashi Ajia ni okeru Tyuruku Tatāru imin no rekishiteki hensen ni kansuru oboegaki.” 戦前の東アジアにおけるテュルク・タタール移民の歴史的变遷に関する覚書. Hokutō Ajia Kenkyrū 10, pp. 45-66.

Yamagishi, Tomoko (2008). “Can Japan Embrace a Muslim Public? A Study on Responses to Newcomer Muslims.” Studia Culturae Islamicae 29:5, pp. 91-118.

Yamashita, Shinji 山下晋司 (2010). “2050 nen no Nihon-Filipiina no yume o meguru jinruigakuteki sōzōryoku.” 2050 年の日本一フィリピーナの夢をめぐる人類学的想像力. Bunka Jinruigaku 75:3, pp. 327-44.

Cite this article: Yamashita Y (2022). Islam and Muslims in "non-religious" Japan: caught in between prejudice against Islam and performative tolerance. International Journal of Asian Studies 19, 81-97. https://doi.org/10.1017/S1479591421000012 